\title{
ANALISIS DAYA HASIL LATEKS DAN HERITABILITAS KARAKTER KUANTITATIF DARI BEBERAPA GENOTIPE KARET PP/07/04
}

\author{
Latex Yield Potential Analysis and Heritability of Quantitative Characters of \\ Some Rubber Genotypes PP/07/04
}

\author{
SAYURANDI ${ }^{1 *}$, Desta WIRNAS ${ }^{2)}$ dan Sekar WOELAN ${ }^{3)}$ \\ ${ }^{1}$ Balai Penelitian Sungei Putih, Pusat Penelitian Karet \\ PO Box 1415 Medan 20001 Sumatera Utara \\ Email: sayurandi_sp@yahoo.com
}

\author{
${ }^{2}$ Program Studi Agronomi dan Hortikultura, Fakultas Pertanian, Institut Pertanian Bogor \\ Jalan Meranti No. 1, Kampus IPB Dramaga, Bogor 16680, Jawa Barat \\ ${ }^{3}$ Pusat Penelitian Karet \\ Jalan Salak Nomor 1 Bogor 16151 Jawa Barat
}

Diterima : 5 April 2016 / Direvisi : 30 Juni 2016 / Disetujui : 3 Agustus 2016

\begin{abstract}
The objectives of the research were to study growth characters, latex yield and heritability of quantitative characters of some rubber genotypes PP/07/04. About fifteen rubber genotypes and two control clones of $P B 260$ and RRIC 100 were tested in this research. The genotypes trial was conducted in 2004 at Experimental Garden, Sungei Putih Research Station, Indonesian Rubber Research Institute which is in Deli Serdang District, North Sumatera Province. The experimental design used Randomized Completely Design (RCD) with three replications. The research results showed that the genotypes had significantly different in twelve observed characters named girth, bark thickness, number of latex vessel rings, diameter of latex vessel cells, length of tapping panel, latex flow rate, plugging index, anorganic phosphate content, sucrose content, thiol content, dry rubber content, and latex yield potential. Based on growth characters and latex yield potential it showed that genotype HP 92/309had high latex yield, while genotype HP 92/542 had high latex yield and vigorous growth. The twelve characters which were observed had high heritability with $h^{2}$ bs value between 0.52 0.95 . It showed that the characters were more influenced by genetic factor.
\end{abstract}

Keywords: Hevea brasiliensis; latex yield potential; heritability; quantitative characters

\section{Abstrak}

Tujuan penelitian ini adalah untuk mempelajari karakter pertumbuhan, daya hasil lateks dan heritabilitas karakter kuantitatif beberapa genotipe karet PP/07/04. Sebanyak lima belas genotipe karet dan dua klon pembanding PB 260 dan RRIC 100 diuji pada penelitian ini. Pengujian genotipe tersebut dibangun di Kebun Percobaan Balai Penelitian Sungei Putih, Pusat Penelitian Karet pada tahun 2004, yang terletak di Kabupaten Deli Serdang Provinsi Sumatera Utara. Rancangan yang digunakan pada penelitian ini adalah Rancangan Acak Lengkap (RAL) dengan tiga ulangan. Hasil penelitian menunjukkan bahwa genotipe berpengaruh nyata terhadap dua belas karakter yang diamati yaitu lilit batang, tebal kulit, jumlah cincin pembuluh lateks, diameter sel pembuluh lateks, panjang alur sadap, kecepatan aliran lateks, indeks penyumbatan, kadar fosfat anorganik, kadar sukrosa, kadar thiol, kadar karet kering, dan daya hasil lateks. Berdasarkan karakter pertumbuhan dan daya hasil lateks menunjukkan bahwa genotipe HP 92/309 memiliki potensi hasil lateks tinggi, sedangkan genotipe HP 92/542 memiliki hasil lateks tinggi dan pertumbuhan jagur. Dua belas karakter yang diamati memiliki nilai heritabilitas tinggi dengan nilai $h^{2}$ bs antara 0,52-0,95. $\mathrm{Hal}$ ini menunjukkan bahwa karakterkarakter tersebut lebih dipengaruhi oleh faktor genetik. 
Kata kunci: Hevea brasiliensis; daya hasil lateks; heritabilitas; karakter kuantitatif

\section{PENDAHULUAN}

Indonesia merupakan negara yang memiliki perkebunan karet terluas di dunia dengan luas areal sekitar 3,56 juta Ha. Namun, produktivitas karet nasional masih tergolong rendah yaitu $1050 \mathrm{~kg} / \mathrm{Ha}$. Rendahnya produktivitas karet Indonesia disebabkan oleh $85 \%$ dari total luas areal merupakan perkebunan karet rakyat yang sebagian besar masih menggunakan bahan tanam dengan kualitas rendah (Direktorat Jenderal Perkebunan [Dirjenbun], 2010). Pemerintah telah menargetkan bahwa Indonesia akan menjadi produsen karet nomor satu dunia pada tahun 2025. Diharapkan dengan menjadi produsen karet nomor satu dunia maka akan lebih mempermudah dalam pengendalian harga karet di pasar dunia serta meningkatkan devisa negara melalui nilai ekspor non migas. Kebijakan pemerintah dalam pencapaian target produksi adalah dengan cara meningkatkan produksi karet nasional sebesar 4 juta ton karet kering atau rata-rata produktivitas karet nasional sebesar 1200 $\mathrm{kg} / \mathrm{Ha}$ (Departemen Pertanian [Deptan], 2014).

Salah satu upaya yang dapat dilakukan untuk mencapai target produksi nasional adalah dengan menyebarluaskan klon-klon karet unggul ke berbagai daerah sentra perkebunan karet. Klon karet unggul menjadi salah satu komponen teknologi terpenting untuk mendukung kinerja dan kesinambungan industri perkaretan nasional yang efisien dan berdaya saing tinggi. Penanaman klon unggul di berbagai perkebunan besar secara nyata telah meningkatkan produktivitas kebun serta efisiensi usaha tani karet (Aidi-Daslin, Sayurandi, \& Pasaribu, 2012).

Kegiatan pemuliaan karet di Indonesia telah menghasilkan berbagai klon karet unggul dengan potensi produktivitas karet yang dihasilkan mencapai lima kali lebih tinggi dibandingkan dengan tanaman karet asal bibit semaian (Woelan, 2013). Klon karet anjuran skala komersial seperti PB 260, PB 330, PB 340, RRIC 100, BPM 24, IRR 112, dan IRR 118 telah banyak dikembangkan di berbagai perkebunan besar dan rakyat dengan produktivitas aktualnya dapat mencapai 2000-2500 $\mathrm{kg} / \mathrm{Ha} / \mathrm{th}$ (Aidi-Daslin et al., 2009; AidiDaslin, 2011).

Upaya untuk mendapatkan klon unggul dilakukan melalui tahapan persilangan, seleksi, dan pengujian klon secara bertahap dengan program pemuliaan karet konvensional. Pengujian genotipe diawali dengan uji keturunan (progeny test) pada populasi tanaman semaian F1 hasil persilangan, uji pendahuluan, uji plot promosi hingga pengujian lanjutan atau multilokasi. Tahapan seleksi dalam kegiatan pemuliaan perlu dilakukan secara sistematis dan berkesinambungan, sehingga potensi keunggulan suatu klon karet dapat diketahui (Aidi-Daslin, 2011).

Materi genetik yang digunakan pada pengujian plot promosi ini merupakan hasil seleksi 1\% genotipe terbaik dari 828 genotipe F1. Genotipe-genotipe tersebut merupakan hasil persilangan dari 31.120 bunga pada tahun 1992. Terseleksi 15 genotipe harapan saat ini masih dalam proses evaluasi di pengujian plot promosi di Kebun Percobaan Balai Penelitian Sungei Putih yang ditanam pada tahun 2004 (Woelan, Sayurandi, \& Pasaribu, 2012).

Kriteria yang digunakan pada proses seleksi genotipe unggul karet adalah karakter pertumbuhan, fisiologi, anatomi kulit dan daya hasil lateks. Karakter fisiologi dan antomi tanaman memiliki pengaruh terhadap hasil lateks (Novalina, 2009; Woelan et al., 2014). Karakter fisiologi yang diduga berkaitan erat terhadap hasil lateks adalah kadar fosfat anorganik, kadar sukrosa, kadar thiol, dan indeks penyumbatan, sedangkan karakter anatomi kulit yang berpengaruh terhadap hasil lateks adalah tebal kulit, jumlah cincin pembuluh lateks, dan diameter sel pembuluh lateks.

Pendugaan nilai komponen ragam dan heritabilitas dilakukan untuk mengetahui proporsi keragaman yang disebabkan oleh faktor genetik dan lingkungan. Heritabilitas merupakan alat ukur dalam kegiatan seleksi pada pemuliaan tanaman terutama pada karakter kuantitatif yang sangat dipengaruhi oleh lingkungan (Woelan, 2013). Karakter kuantitatif merupakan karakter yang dikendalikan oleh 
banyak gen yang masing-masing mempunyai pengaruh kecil sehingga mudah dipengaruhi oleh lingkungan. Karakter kuantitatif memiliki sebaran kontinyu dan dapat diukur. Kajian terhadap karakter kuantitatif sangat bermanfaat untuk menyeleksi klon karet unggul harapan terutama pada karakter-karakter yang memiliki nilai heritabilitas tinggi (Syukur, Sujiprihati, \& Yunianti, 2012). Penelitian ini bertujuan untuk mempelajari karakter pertumbuhan, hasil lateks dan heritabilitas beberapa karakter kuantitatif pada beberapa genotipe karet $\mathrm{PP} / 07 / 04$.

\section{BAHAN DAN METODE}

Pengujian plot promosi dari lima belas genotipe karet harapan dan dua klon pembanding PB 260 dan RRIC 100 dibangun di Kebun Percobaan Balai Penelitian Sungei Putih, Pusat Penelitian Karet pada tahun 2004, Kabupaten Deli Serdang, Provinsi Sumatera Utara yang terletak pada ketinggian $\pm 54 \mathrm{~m}$ di atas permukaan laut (dpl) dan berada pada posisi $3^{\circ}$ arah utara khatulistiwa. Klasifikasi jenis tanah digolongkan ke dalam tanah ultisol. Jumlah rata-rata curah hujan pada sepuluh tahun terakhir adalah $1984 \mathrm{~mm}$. Penelitian dilaksanakan pada bulan Agustus Desember 2015. Materi genetik yang digunakan pada pengujian plot promosi $\mathrm{PP} / 07 / 04$ terdiri dari 15 genotipe harapan yaitu HP 92/109, HP 92/179, HP 92/211, HP 92/309, HP 92/327, HP 92/366, HP 92/368, HP 92/388, HP 92/542, HP 92/669, HP 92/677, HP 92/704, HP 92/ 711, HP 92/726, HP 92/838 dan dua klon pembanding yaitu klon PB 260 dan RRIC 100. Penelitian disusun dengan menggunakan Rancangan Acak Lengkap (RAL) dengan tiga ulangan. Masing-masing genotipe terdiri dari enam puluh tanaman yang dibagi menjadi tiga satuan percobaan dan setiap satuan percobaan terdiri dari dua puluh tanaman. Jarak tanam yang digunakan yaitu $5 \mathrm{mx} 4 \mathrm{~m}$.

Parameter yang diamati pada saat tanaman menghasilkan (TM) berumur 11 tahun meliputi: 1) lilit batang tanaman, 2) tebal kulit, 3) jumlah cincin pembuluh lateks, 4) diameter sel pembuluh lateks, 5) panjang alur sadap, 6) kecepatan aliran lateks, 7) indeks penyumbatan, 8) kadar fosfat anorganik, 9) kadar sukrosa, 10) kadar thiol, 11) kadar karet kering, dan 12) hasil lateks. Sistem sadap yang digunakan yaitu sistem sadap $\mathrm{S} / 2$ d3. Dalam penelitian ini dilakukan analisis data hasil lateks dari TM 1 sampai dengan TM 6. Data ini diperoleh dari pengamatan yang telah dilakukan sebelumnya.

Analisis data yang dilakukan untuk semua peubah yang diamati dengan menggunakan analisis ragam (Anova). Jika perlakuan menunjukkan pengaruh nyata maka dilakukan uji lanjut dengan menggunakan Honest Significance Difference (HSD). Untuk daya hasil lateks (TM-1 sampai dengan TM-6) dianalisis dengan menguji nilai tengah setiap genotipe dengan klon pembanding PB 260 menggunakan analisis uji t-student. Analisis parameter genetik, koefisien keragaman genetik, dan heritabilitas dihitung dengan menggunakan rumus yang dikembangkan oleh Alnopri (2014).

\section{HASIL DAN PEMBAHASAN}

\section{Pertumbuhan Lilit Batang dan Anatomi Kulit}

Data hasil pengam at a n pertumbuhan lilit batang dan anatomi kulit disajikan pada Tabel 1. Hasil analisis menunjukkan bahwa genotipe berpengaruh nyata terhadap karakter lilit batang, tebal kulit, jumlah cincin pembuluh lateks, dan diameter sel pembuluh lateks.

Tabel 1 menunjukkan bahwa genotipe HP 92/366 dan HP 92/542 memiliki pertumbuhan lilit batang paling tinggi umur 11 tahun yaitu masing-masing sebesar 79,46 cm dan 76,88 cm, sedangkan genotipe HP 92/726 dan HP 92/838 memiliki pertumbuhan lilit batang paling rendah yaitu masing-masing sebesar 56,38 $\mathrm{cm}$ dan 55,67 cm. Genotipe lainnya memiliki ukuran lilit batang antara 58,24-70,50 cm dan klon pembanding RRIC 100 dan PB 260 masing-masing sebesar $68,06 \mathrm{~cm}$ dan 63,96 $\mathrm{cm}$. Karakter pertumbuhan lilit batang merupakan salah satu karakter penting dalam seleksi klon karet unggul. Klon karet yang memiliki pertumbuhan jagur diharapkan dapat memperpendek masa tanaman belum menghasilkan sehingga mempercepat penyadapan (Siagian \& Siregar, 2013). Menurut Novalina (2009), 
Tabel 1. Pertumbuhan lilit batang dan anatomi kulit 15 genotipe karet harapan PP/07/04 pada umur 11 tahun.

Table 1. Girth growth and bark anatomy of 15 rubber promising genotypes PP/07/04 at 11 years old.

\begin{tabular}{lllll}
\hline Genotipe & $\begin{array}{c}\text { Lilit batang } \\
\text { Girth } \\
(\mathrm{cm})\end{array}$ & $\begin{array}{c}\text { Tebal kulit } \\
\text { Bark } \\
\text { thickness } \\
(\mathrm{mm})\end{array}$ & $\begin{array}{c}\text { Jumlah cincin } \\
\text { pembuluh } \\
\text { lateks } \\
\text { Number of latex } \\
\text { vessel rings }\end{array}$ & $\begin{array}{c}\text { Diameter pembuluh } \\
\text { lateks } \\
\text { Diameter of latex } \\
\text { vessel cells } \\
(\mu \mathrm{m})\end{array}$ \\
\hline HP 92/109 & $58,24 \mathrm{de}$ & $8,83 \mathrm{ab}$ & $14,33 \mathrm{ab}$ & $23,98 \mathrm{bc}$ \\
HP 92/179 & $60,17 \mathrm{cde}$ & $10,17 \mathrm{a}$ & $14,31 \mathrm{ab}$ & $19,35 \mathrm{fg}$ \\
HP 92/211 & $70,50 \mathrm{abc}$ & $9,50 \mathrm{a}$ & $10,67 \mathrm{ab}$ & $21,46 \mathrm{cdef}$ \\
HP 92/309 & $63,83 \mathrm{cde}$ & $9,83 \mathrm{a}$ & $15,50 \mathrm{ab}$ & $26,42 \mathrm{ab}$ \\
HP 92/327 & $67,03 \mathrm{bcde}$ & $9,67 \mathrm{a}$ & $15,00 \mathrm{ab}$ & $20,79 \mathrm{def}$ \\
HP 92/366 & $79,46 \mathrm{a}$ & $7,43 \mathrm{~b}$ & $15,83 \mathrm{ab}$ & $23,21 \mathrm{~cd}$ \\
HP 92/368 & $69,58 \mathrm{abcd}$ & $9,00 \mathrm{a}$ & $10,50 \mathrm{ab}$ & $20,27 \mathrm{efg}$ \\
HP 92/388 & $64,29 \mathrm{cde}$ & $9,54 \mathrm{a}$ & $9,33 \mathrm{~b}$ & $20,98 \mathrm{def}$ \\
HP 92/542 & $76,88 \mathrm{ab}$ & $10,00 \mathrm{a}$ & $16,50 \mathrm{ab}$ & $27,29 \mathrm{a}$ \\
HP 92/669 & $66,33 \mathrm{bcde}$ & $9,13 \mathrm{a}$ & $15,50 \mathrm{ab}$ & $20,04 \mathrm{efg}$ \\
HP 92/677 & $58,29 \mathrm{de}$ & $8,92 \mathrm{a}$ & $13,67 \mathrm{ab}$ & $21,88 \mathrm{cdef}$ \\
HP 92/704 & $63,75 \mathrm{cde}$ & $9,04 \mathrm{a}$ & $12,33 \mathrm{ab}$ & $17,96 \mathrm{~g}$ \\
HP 92/711 & $62,96 \mathrm{cde}$ & $9,54 \mathrm{a}$ & $15,67 \mathrm{ab}$ & $20,38 \mathrm{efg}$ \\
HP 92/726 & $56,38 \mathrm{e}$ & $9,04 \mathrm{a}$ & $17,00 \mathrm{ab}$ & $22,29 \mathrm{cde}$ \\
HP 92/838 & $55,67 \mathrm{e}$ & $8,88 \mathrm{a}$ & $10,67 \mathrm{ab}$ & $21,17 \mathrm{def}$ \\
RRIC 100 & $68,06 \mathrm{abcd}$ & $9,33 \mathrm{a}$ & $11,83 \mathrm{ab}$ & $22,29 \mathrm{cde}$ \\
PB 260 & $63,96 \mathrm{cde}$ & $9,32 \mathrm{a}$ & $19,83 \mathrm{a}$ & $24,23 \mathrm{bc}$ \\
\hline
\end{tabular}

Angka yang diikuti dengan huruf yang sama pada satu kolom menunjukkan tidak berbeda nyata menurut uji $H S D$ pada taraf $5 \%$.

Figures followed by the same letter in the same column are not significantly different based on HSD test at $5 \%$ level

karakter lilit batang memiliki hubungan yang cukup kuat terhadap hasil lateks sebab ukuran lilit batang akan mempengaruhi panjangnya alur sadap yang mengeluarkan lateks pada pohon karet.

Seleksi klon karet berdasarkan pertumbuhan tanaman pada masa tanaman menghasilkan (TM) berkaitan dengan potensi kayu yang akan dihasilkan pada saat peremajaan tanaman (replanting). Pemanfaatan kayu karet pada saat ini berkembang secara cepat, baik untuk bahan baku industri perabotan maupun jenis papan partikel. Untuk itu, seleksi klon tidak hanya memperoleh klon unggul sebagai penghasil lateks saja, namun juga diarahkan untuk klon penghasil lateks-kayu (Aidi-Daslin, 2012). Berdasarkan pertumbuhan tanaman memperlihatkan genotipe HP 92/366 dan HP 92/542 berpotensi dikembangkan menjadi klon penghasil lateks-kayu.
Tabel 1 menunjukkan bahwa genotipe berpengaruh nyata terhadap tebal kulit, jumlah cincin pembuluh lateks dan diameter sel pembuluh lateks. Genotipe yang memiliki tebal kulit paling tinggi yaitu HP 92/179 (10,17 mm) dan HP 92/542 $(10,00 \mathrm{~mm})$, sedangkan yang paling rendah terdapat pada genotipe HP 92/109 $(8,83$ $\mathrm{mm})$ dan HP 92/366 (7,43 mm). Pada umumnya tebal kulit pada masing-masing genotipe tidak berbeda nyata. Tebal kulit merupakan salah satu parameter yang sering diamati dalam seleksi tanaman karet karena berkontribusi secara langsung maupun tidak langsung terhadap hasil lateks. Ukuran tebal kulit merupakan salah satu kriteria tanaman untuk dapat disadap yaitu minimal $7 \mathrm{~mm}$. Pada ukuran tersebut diharapkan tanaman lebih toleran terhadap peluka an sa at penyad a a n (Annamalainathan, Krihsnakumar, \& Jacob, 2001). Menurut Woelan, Sayurandi, dan Pasaribu (2013), seleksi pada karakter tebal 
kulit adalah untuk mendapatkan genotipe dengan ukuran kulit cukup tebal. Menurut Aidi-Daslin (2012), ketebalan kulit murni berpengaruh terhadap kemudahan untuk menyadap pohon karet serta potensi hasil lateks.

Berdasarkan parameter jumlah cincin pembuluh lateks menunjukkan bahwa klon pembanding PB 260 memiliki jumlah cincin pembuluh lateks paling tinggi (19,83 pembuluh), sedangkan paling rendah terdapat pada genotipe HP 92/388 (9,33 pembuluh). Genotipe lainnya memiliki jumlah cincin pembuluh lateks antara 10,50 - 17,00 pembuluh. Berdasarkan parameter diameter sel pembuluh lateks menunjukkan bahwa genotipe HP 92/542 memiliki diameter sel pembuluh lateks paling lebar yaitu sebesar $27,29 \mu \mathrm{m}$, sedangkan paling sempit terdapat pada genotipe HP 92/704 $(17,96 \mu \mathrm{m})$.

Dari beberapa hasil penelitian menunjukkan bahwa jumlah cincin pembuluh lateks dan diameter sel pembuluh lateks memberikan kontribusi yang nyata terhadap hasil lateks pada tanaman karet (Obouayeba et al., 2012; Woelan et al., 2013; Purwaningrum et al., 2015). Klon yang memiliki jumlah cincin dan diameter sel pembuluh lateks paling lebar pada umumnya menghasilkan lateks paling banyak, hal tersebut dapat dipahami bahwa semakin banyak pembuluh lateks yang tersayat pada saat penyadapan maka semakin banyak pula lateks yang dapat dikeluarkan. Menurut Gomez, Narayanan, dan Chen (1982), pembuluh lateks merupakan diferensiasi dari kambium vaskular pada jaringan tanaman yang dikendalikan secara genetik. Aidi-Daslin, Woelan, Lasminingsih, dan Hadi (2009) mengemukakan bahwa pemuliaan tanaman karet selama lima kali siklus telah berhasil meningkatkan jumlah cincin nembuluh lateks dari klon yang dihe

menyebabkan terjadinya peningkatan hasil lateks menjadi tujuh kali lipat.

\section{Karakter Fisiologi dan Sifat Aliran Lateks}

Karakter fisiologi pada tanaman karet erat hubungannya dengan kemampuan tanaman untuk mensintesis assimilat menjadi bahan pembentuk lateks. Karakter fisiologi yang berpengaruh dalam pembentukan lateks diantaranya adalah kandungan sukrosa, fosfat anorganik, dan kadar thiol (Novalina et al., 2008; Herlinawati \& Kuswanhadi, 2013; Woelan et al., 2013). Hasil analisis uji beda rataan menunjukkan bahwa karakter fisiologi lateks genotipe $\mathrm{PP} / 07 / 04$ berbeda nyata pada setiap karakter yang diamati seperti yang disajikan pada Tabel 2 .

Tabel 2 menunjukkan genotipe berpengaruh nyata terhadap parameter kadar sukrosa. Kadar sukrosa paling tinggi terdapat pada genotipe HP 92/309 $(17,82$ $\mathrm{mM})$, sedangkan yang paling rendah terdapat pada genotipe HP 92/109 $(2,26$ $\mathrm{mM}$ ). Genotipe lainnya memiliki kadar sukrosa berkisar 3,41-10,43 mM. Sukrosa merupakan bentuk utama sakarida yang berada di dalam sel pembuluh lateks (laticiferous cells) yang dihasilkan melalui proses biosintesis yang diawali dengan pemecahan assimilat hasil fotosintesis. Senyawa ini merupakan prekusor untuk sintesis cis-poliisoprena atau partikel karet (Rachmawan \& Sumarmadji, 2007)

Kadar sukrosa tinggi yang terdapat di dalam suatu genotipe karet belum tentu menghasilkan suatu genotipe dengan hasil lateks tinggi. Kadar sukrosa tidak memiliki arti langsung sebagai gambaran potensi produksinya, namun terdapat batas kritis kadar sukrosa yang harus tersedia dalam sel pembuluh lateks untuk sintesis partikel karet (Atminingsih, 2015). Kandungan sukrosa tinggi menunjukkan adanya influks yang cukup baik dalam sel pembuluh lateks yang mungkin diikuti oleh suatu metabolisme sel yang aktif, namun kandungan sukrosa yang tinggi mungkin juga disebabkan oleh rendahnya metabolisme penggunaan sukrosa yang menyebabkan produksi aktual menjadi rendah.

Hasil analisis menunjukkan bahwa genotipe berpengaruh nyata terhadap kadar fosfat anorganik. Genotipe HP 92/542 memiliki kadar fosfat anorganik paling tinggi (20,87 $\mathrm{mM})$, sedangkan yang paling rendah terdapat pada genotipe HP 92/838 $(8,03$ $\mathrm{mM})$. Genotipe lainnya memiliki kadar fosfat anorganik berkisar 9,20-17,57 mM. Kadar fosfat anorganik tinggi mencerminkan metabolisme yang aktif, karena fosfat berfungsi sebagai senyawa fosforilasi dan 
Tabel 2. Karakter fisiologi lateks 15 genotipe karet harapan PP/07/04 umur 11 tahun Table 2. Latex physiology characters of 15 rubber promising genotypes PP/07/04 at 11 years old

\begin{tabular}{cccc}
\hline $\begin{array}{c}\text { Genotipe } \\
\text { Genotypes }\end{array}$ & $\begin{array}{c}\text { Kadar sukrosa } \\
\text { Sucrose content } \\
(\mathrm{mM})\end{array}$ & $\begin{array}{c}\text { Kadar fosfat anorganik } \\
\text { Anorganic phosphate } \\
\text { content } \\
(\mathrm{mM})\end{array}$ & $\begin{array}{c}\text { Kadar thiol } \\
\text { Thiol content } \\
(\mathrm{mM})\end{array}$ \\
\hline HP 92/109 & $2,26 \mathrm{f}$ & $17,57 \mathrm{ab}$ & $0,56 \mathrm{bc}$ \\
HP 92/179 & $3,99 \mathrm{def}$ & $17,43 \mathrm{ab}$ & $0,68 \mathrm{~b}$ \\
HP 92/211 & $7,84 \mathrm{bcde}$ & $17,50 \mathrm{ab}$ & $1,02 \mathrm{a}$ \\
HP 92/309 & $17,82 \mathrm{a}$ & $12,28 \mathrm{bcd}$ & $0,47 \mathrm{bc}$ \\
HP 92/327 & $3,54 \mathrm{ef}$ & $14,22 \mathrm{abcd}$ & $0,41 \mathrm{bc}$ \\
HP 92/366 & $5,40 \mathrm{cdef}$ & $13,27 \mathrm{bcd}$ & $0,35 \mathrm{c}$ \\
HP 92/368 & $4,66 \mathrm{cdef}$ & $15,35 \mathrm{abc}$ & $0,57 \mathrm{bc}$ \\
HP 92/388 & $9,24 \mathrm{bc}$ & $13,80 \mathrm{abcd}$ & $0,53 \mathrm{bc}$ \\
HP 92/542 & $3,41 \mathrm{ef}$ & $20,87 \mathrm{a}$ & $0,59 \mathrm{bc}$ \\
HP 92/669 & $3,59 \mathrm{ef}$ & $10,55 \mathrm{bcd}$ & $0,62 \mathrm{bc}$ \\
HP 92/677 & $3,51 \mathrm{ef}$ & $14,58 \mathrm{abcd}$ & $0,44 \mathrm{bc}$ \\
HP 92/704 & $3,69 \mathrm{def}$ & $12,23 \mathrm{bcd}$ & $0,47 \mathrm{bc}$ \\
HP 92/711 & $10,43 \mathrm{~b}$ & $13,13 \mathrm{bcd}$ & $0,46 \mathrm{bc}$ \\
HP 92/726 & $4,56 \mathrm{cdef}$ & $13,42 \mathrm{bcd}$ & $0,39 \mathrm{c}$ \\
HP 92/838 & $8,57 \mathrm{bcd}$ & $8,03 \mathrm{~d}$ & $0,43 \mathrm{bc}$ \\
RRIC 100 & $5,48 \mathrm{cdef}$ & $9,20 \mathrm{~cd}$ & $0,40 \mathrm{bc}$ \\
PB 260 & $4,34 \mathrm{cdef}$ & $14,15 \mathrm{abcd}$ & $0,37 \mathrm{c}$ \\
\hline
\end{tabular}

Angka yang diikuti dengan huruf yang sama pada satu kolom menunjukkan tidak berbeda nyata menurut uji HSD pada taraf $5 \%$.

Figures followed by the same letter in the same column are not significantly different based on HSD test at $5 \%$ level

sebagai komponen pembentuk energi (Zambrosi et al., 2012; Mirabello et al., 2013). Atminingsih (2015) menyatakan bahwa proses regenerasi lateks, pemecahan sukrosa menjadi glukosa hingga terbentuknya partikel karet sangat memerlukan energi. Kandungan fosfat anorganik dapat dijadikan indikator terhadap energi dan metabolisme tanaman. Menurut Sumarmadji dan Tistama (2004), kadar fosfat anorganik menggambarkan ketersediaan energi pada sel-sel pembuluh lateks untuk mengubah sukrosa menjadi partikel karet. Kisaran optimum kadar fosfat anorganik adalah $10-20 \mathrm{mM}$, sehingga apabila tanaman memiliki kadar fosfat anorganik < $10 \mathrm{mM}$, maka metabolisme tanaman menjadi kurang aktif.

Tabel 2 juga menunjukkan bahwa genotipe berpengaruh nyata terhadap kadar thiol. Kadar thiol paling tinggi terdapat pada genotipe HP 92/211 (1,02 mM), sedangkan yang paling rendah terdapat pada genotipe HP 92/366 (0,35 mM), HP 92/ 726 (0,39 mM), dan klon pembanding PB $260(0,37 \mathrm{mM})$.
Genotipe lainnya memiliki kadar thiol berkisar 0,40 - 0,68 mM. Kadar thiol di dalam sel pembuluh lateks berfungsi sebagai aktivator enzim dan berhubungan dengan stabilitas membran lutoid untuk memperpanjang lama aliran lateks. Thiol mempunyai kemampuan melindungi organel subseluler dan menangkap molekul oksigen toksik seperti $\mathrm{O}_{2}^{-}, \mathrm{H}_{2} \mathrm{O}_{2}$ dan $\mathrm{OH}$ (Atminingsih, 2015). Menurut Sumarmadji dan Tistama (2004) kandungan thiol yang optimum berkisar 0,4 - 0,9 m . Peningkatan intensitas penyadapan (exploitation intensity) berpengaruh pada peningkatan kadar thiol, namun jika intensitas penyadapan berlebihan menyebabkan kadar thiol menjadi rendah kembali.

Hasil lateks pada tanaman karet, selain dipengaruhi oleh karakter fisiologi tetapi juga dipengaruhi oleh sifat aliran lateks yang diantaranya adalah panjang alur sadap, kecepatan aliran lateks, indeks penyumbatan, dan kadar karet kering. Keempat parameter tersebut juga dapat 
dipertimbangkan dalam melakukan seleksi klon karet unggul. Data hasil pengamatan panjang alur sadap, kecepatan aliran lateks, indeks penyumbatan, dan kadar karet kering lima belas genotipe PP/07/04 umur sebelas tahun disajikan pada Tabel 3 . Berdasarkan hasil analisis statistik menunjukkan bahwa genotipe berpengaruh nyata terhadap panjang alur sadap, kecepatan aliran lateks, indeks penyumbatan, dan kadar karet kering lateks.

Hasil analisis menunjukkan bahwa genotipe berpengaruh nyata terhadap panjang alur sadap. Genotipe HP 92/366 dan HP 92/542 memiliki panjang alur sadap paling tinggi yaitu sebesar $44,88 \mathrm{~cm}$ dan $43,71 \mathrm{~cm}$, sedangkan yang paling rendah terdapat pada genotipe HP 92/726 (29,96 $\mathrm{cm})$ dan HP 92/838 (29,38 cm). Genotipe lainnya memiliki panjang alur sadap berkisar 32,54 - 40,67 cm. Panjang alur sadap memiliki pengaruh positif terhadap hasil lateks pada klon-klon penghasil lateks tinggi. Novalina (2009) menyatakan bahwa semakin panjang alur sadap maka akan menyebabkan pembuluh lateks yang terpotong semakin banyak sehingga akan berpengaruh terhadap hasil lateks.

Hasil analisis menunjukkan bahwa genotipe berpengaruh nyata terhadap kecepatan aliran lateks. Genotipe HP 92/542 memiliki kecepatan aliran lateks paling cepat $(33,10 \mathrm{ml} /$ menit), sedangkan yang paling lambat terdapat pada genotipe HP 92/726 (7,52 ml/menit). Genotipe lainnya memiliki kecepatan aliran lateks berkisar 9,38 - 26,97 ml/menit. Woelan et al. (2013) menyatakan bahwa kecepatan aliran lateks pada tanaman karet merupakan sifat fisiologis penting dalam menentukan variasi potensi hasil antar klon karet. Menurut Novalina (2009), klon karet yang memiliki kecepatan aliran lateks tinggi diharapkan potensi hasil lateksnya juga tinggi. Kecepatan aliran lateks mengalir sewaktu disadap berpengaruh terhadap tinggi rendahnya hasil lateks. Perbedaan aliran lateks pada setiap klon sangat dipengaruhi oleh banyaknya pembuluh lateks yang terpotong.

Tabel 3 menunjukkan bahwa genotipe berpengaruh nyata terhadap indeks penyumbatan. Genotipe HP 92/366 memiliki indeks penyumbatan paling tinggi $(32,39 \%)$, sedangkan yang paling rendah terdapat pada genotipe HP 92/711 (8,41\%). Genotipe lainnya memiliki indeks penyumbatan berkisar 10,28-28,81\%. Indeks penyumbatan sangat berkaitan erat dengan hasil lateks karena mencerminkan lama aliran lateks. Indeks penyumbatan tinggi mengakibatkan aliran lateks lebih cepat berhenti. Proses koagulasi lateks dalam jaringan saluran pembuluh lateks akan mempercepat terhentinya aliran lateks, sebaliknya indeks penyumbatan yang rendah memicu lateks mengalir lebih lama sehingga lateks yang keluar menjadi lebih banyak (Novalina, 2009).

Penyumbatan pembuluh lateks terjadi karena koagulasi partikel karet di dalam pembuluh lateks sehingga mempengaruhi lama lateks mengalir. Flokulasi partikel karet terjadi akibat adanya kerusakan pada membran lutoid sehingga menyebabkan aliran lateks menjadi terhenti (Atminingsih, 2015). Klon dengan indeks penyumbatan rendah akan memberikan hasil lateks tinggi. Proses penyumbatan aliran lateks tidak sama untuk setiap klon, sehingga indeks penyumbatan dapat digunakan sebagai penciri spesifik dari masing-masing klon (Aidi-Daslin et al.; 2009). Milford, Paardekooper dan Ho (1969) membuktikan bahwa produksi lateks sangat efektif pada tanaman yang memiliki indeks penyumbatan rendah. Klon yang demikian akan memperlihatkan waktu aliran yang lebih lama sehingga menghasilkan lateks lebih banyak.

Hasil analisis menunjukkan bahwa genotipe berpengaruh nyata terhadap kadar karet kering (KKK). Genotipe HP 92/ 838 memiliki KKK paling tinggi $(36,09 \%)$, sedangkan yang paling rendah terdapat pada genotipe HP 92/368 (25,11\%). Genotipe lainnya memiliki KKK berkisar $27,17-35,99 \%$. Pada umumnya klon yang memiliki KKK tinggi memiliki indeks penyumbatan tinggi yang menyebabkan aliran lateks lebih cepat berhenti. Walaupun demikian, lateks yang memiliki KKK tinggi diharapkan akan menghasilkan klon berproduktivitas tinggi. Kadar karet tinggi terutama disebabkan oleh viskositas lateks tinggi yang menyebabkan proses 
Tabel 3. Karakter panjang alur sadap, kecepatan aliran lateks, indeks penyumbatan dan kadar karet kering 15 genotipe karet harapan PP/07/04 umur 11 tahun.

Table 3. Length of tapping panel, latex flow rate, plugging index and dry rubber content characters of 15 promising rubber genotypes PP/07/04 at 11 years old

\begin{tabular}{|c|c|c|c|c|}
\hline $\begin{array}{l}\text { Genotipe } \\
\text { Genotypes }\end{array}$ & $\begin{array}{l}\text { Panjang alur } \\
\text { sadap } \\
\text { Length of } \\
\text { tapping panel } \\
\text { (cm) }\end{array}$ & $\begin{array}{c}\text { Kecepatan } \\
\text { aliran lateks } \\
\text { (ml/menit) } \\
\text { Latex flow rate } \\
\text { (ml/minute) }\end{array}$ & $\begin{array}{c}\text { Indeks } \\
\text { penyumbatan } \\
\text { Plugging index } \\
(\%)\end{array}$ & $\begin{array}{c}\text { Kadar karet kering } \\
\text { Dry rubber content } \\
(\%)\end{array}$ \\
\hline HP 92/109 & $34,13 \mathrm{bcd}$ & $17,10 \mathrm{bcde}$ & 15,74 cde & $31,30 a b c$ \\
\hline HP 92/ 179 & $33,42 \mathrm{~cd}$ & 17,70 abcde & $15,53 \mathrm{cde}$ & $31,62 \mathrm{abc}$ \\
\hline HP $92 / 211$ & $38,96 a b c d$ & $18,38 \mathrm{abcde}$ & $19,28 \mathrm{bcd}$ & $30,83 \mathrm{abc}$ \\
\hline HP 92/309 & $34,17 \mathrm{bcd}$ & 23,81abcd & $20,78 \mathrm{bc}$ & $34,23 a b$ \\
\hline HP 92/327 & $40,67 \mathrm{abc}$ & $11,52 \mathrm{bcde}$ & $17,37 \mathrm{cde}$ & $30,13 a b c$ \\
\hline HP 92/366 & $44,88 \mathrm{a}$ & $26,97 a b$ & $32,39 a$ & $34,99 \mathrm{ab}$ \\
\hline HP 92/368 & $40,58 \mathrm{abc}$ & $15,89 \mathrm{bcde}$ & $16,28 \mathrm{cde}$ & $25,11 \mathrm{c}$ \\
\hline HP 92/388 & $35,63 \mathrm{abcd}$ & 11,39 bcde & $14,95 \mathrm{cde}$ & $27,17 \mathrm{bc}$ \\
\hline HP 92/542 & $43,71 \mathrm{ab}$ & $33,10 \mathrm{a}$ & $28,81 \mathrm{ab}$ & $33,97 a b$ \\
\hline HP 92/669 & $38,00 a b c d$ & $25,40 a b c$ & $19,27 \mathrm{bcd}$ & $35,80 \mathrm{ab}$ \\
\hline HP 92/677 & $33,54 \mathrm{~cd}$ & $10,25 \mathrm{cde}$ & $15,36 \mathrm{cde}$ & $28,55 a b c$ \\
\hline HP 92/704 & $32,54 \mathrm{~cd}$ & $13,67 \mathrm{bcde}$ & $17,28 \mathrm{cde}$ & $33,89 \mathrm{abc}$ \\
\hline HP 92/711 & $33,75 \mathrm{~cd}$ & $9,584 \mathrm{de}$ & $8,41 \mathrm{e}$ & $32,25 a b c$ \\
\hline HP $92 / 726$ & $29,96 d$ & $7,52 \mathrm{e}$ & $15,74 \mathrm{cde}$ & $28,24 a b c$ \\
\hline HP $92 / 838$ & $29,38 d$ & $9,38 \mathrm{de}$ & $10,28 \mathrm{de}$ & $36,09 a$ \\
\hline RRIC 100 & $36,94 \mathrm{abcd}$ & 22,21 abcde & $19,27 \mathrm{bcd}$ & $34,63 a b$ \\
\hline PB 260 & $36,17 \mathrm{abcd}$ & $11,29 \mathrm{cde}$ & $16,83 \mathrm{cde}$ & $35,99 a$ \\
\hline
\end{tabular}

Angka yang diikuti dengan huruf yang sama pada satu kolom menunjukkan tidak berbeda nyata menurut uji HSD pada taraf $5 \%$.

Figures followed by the same letter in the same column are not significantly different based on HSD test at $5 \%$ level

penyumbatan aliran lateks berjalan lebih cepat (Atminingsih, 2015).

\section{Daya Hasil Lateks Beberapa Genotipe PP/07/04}

Data hasil pengamatan hasil lateks dalam bentuk gram per pohon per sadap $(\mathrm{g} / \mathrm{p} / \mathrm{s})$ selama 6 tahun disajikan pada Tabel 4. Berdasarkan hasil analisis statistik menunjukkan bahwa beberapa genotipe memiliki hasil lateks yang berbeda nyata dengan klon pembanding PB 260.

Tabel 4 menunjukkan bahwa genotipe HP 92/309 dan HP 92/542 memiliki hasil lateks $(\mathrm{g} / \mathrm{p} / \mathrm{s})$ paling tinggi selama enam tahun sadap yaitu masingmasing sebesar 46,82 g dan 46,24 g. Hasil lateks dari kedua klon tersebut nyata lebih tinggi dibandingkan dengan klon pembanding PB $260(40,67 \mathrm{~g})$ dan RRIC 100
(37,86 g). Genotipe HP 92/677 dan HP 92/368 merupakan genotipe yang memiliki hasil lateks paling rendah yaitu masingmasing sebesar $32,15 \mathrm{~g}$ dan 33,32 g. Genotipe lainnya memiliki hasil lateks berkisar 34,45 - 39,36 g. Pada Tabel 4 juga menunjukkan bahwa hasil lateks pada sadap tahun pertama (TM-1) sampai dengan tahun ke enam (TM-6) berfluktuatif. Hampir semua genotipe memiliki hasil lateks rendah pada tahun pertama dan sejalan bertambahnya umur tanaman maka hasil lateks menjadi lebih tinggi akibat bertambahnya ukuran lilit batang tanaman, sehingga panjang alur sadap semakin bertambah. Terpotongnya alur sadap yang lebih panjang menyebabkan pembuluh lateks yang tersayat semakin banyak, sehingga menyebabkan hasil lateks semakin tinggi. Selain itu, jumlah cincin pembuluh lateks meningkat dengan bertambahnya umur tanaman. Gambar 1 menunjukkan 
Tabel 4. Daya hasil lateks 15 genotipe karet harapan PP/07/04 selama 6 tahun sadap.

Table 4. Latex yield potential of rubber promising genotypes PP/07/04 for 6 years of tapping.

\begin{tabular}{|c|c|c|c|c|c|c|c|}
\hline \multirow{2}{*}{$\begin{array}{l}\text { Genotipe } \\
\text { Genotypes }\end{array}$} & \multicolumn{6}{|c|}{$\begin{array}{l}\text { Hasil lateks }(\mathrm{g} / \mathrm{p} / \mathrm{s}) \text { tahun sadap ke } \\
\text { Latex yield }(\mathrm{g} / \mathrm{t} / \mathrm{t}) \text { year of tapping }\end{array}$} & \multirow{2}{*}{$\begin{array}{l}\text { Rata-rata hasil lateks } \\
\text { (g/p/s) } \\
\text { Latex yield average } \\
(\mathrm{g} / \mathrm{t} / \mathrm{t})\end{array}$} \\
\hline & 1 & 2 & 3 & 4 & 5 & 6 & \\
\hline HP 92/ 109 & 14,92 & 31,48 & 36,96 & 43,08 & 45,58 & 34,69 & $34,45^{* *}$ \\
\hline HP 92/ 179 & 20,76 & 40,62 & 42,05 & 39,18 & 33,08 & 38,02 & $35,62^{* *}$ \\
\hline HP 92/211 & 26,31 & 39,12 & 40,43 & 45,20 & 46,80 & 36,10 & $38,99 \mathrm{~ns}$ \\
\hline HР 92/309 & 26,54 & 44,60 & 47,97 & 54,82 & 58,80 & 48,20 & $46,82^{* *}$ \\
\hline HP 92/327 & 21,96 & 33,74 & 39,50 & 45,24 & 43,44 & 30,83 & $35,79 *$ \\
\hline HP 92/366 & 28,22 & 33,67 & 44,85 & 44,02 & 42,00 & 41,04 & $38,97 \mathrm{~ns}$ \\
\hline HP 92/368 & 18,47 & 30,21 & 36,71 & 48,77 & 38,34 & 27,43 & $33,32^{* *}$ \\
\hline HP 92/388 & 29,51 & 28,94 & 40,23 & 45,76 & 48,32 & 23,76 & $36,09 *$ \\
\hline HP 92/ 542 & 20,14 & 48,00 & 50,35 & 54,60 & 50,45 & 53,92 & $46,24 * *$ \\
\hline HР 92/669 & 12,65 & 33,02 & 54,51 & 39,26 & 31,49 & 39,88 & $35,14^{* *}$ \\
\hline HP 92/677 & 18,49 & 34,27 & 42,85 & 40,43 & 33,81 & 23,06 & $32,15^{* *}$ \\
\hline HP 92/704 & 36,19 & 32,00 & 42,60 & 40,48 & 36,42 & 28,39 & $36,01^{*}$ \\
\hline HP 92/711 & 17,79 & 30,28 & 47,02 & 47,17 & 32,36 & 33,27 & $34,65^{* *}$ \\
\hline HP 92/726 & 29,93 & 42,49 & 50,50 & 49,54 & 44,80 & 18,92 & $39,36 \mathrm{~ns}$ \\
\hline HP 92/838 & 17,60 & 37,89 & 55,43 & 48,97 & 32,97 & 34,85 & $37,95^{*}$ \\
\hline RRIC 100 & 25,98 & 43,38 & 38,44 & 43,27 & 34,77 & 41,34 & $37,86^{*}$ \\
\hline PB 260 & 28,60 & 44,35 & 40,70 & 45,80 & 40,80 & 43,79 & 40,67 \\
\hline
\end{tabular}

Keterangan (Remaks) *,** = berbeda nyata dan sangat berbeda nyata dengan klon pembanding PB 260 berdasarkan uji t pada taraf $5 \%$ dan $1 \%$ (significantly and highly significantly different compared with control clone of PB 260 based on t-test at 5\% and 1\%) ns = tidak berbeda nyata dengan klon pembanding PB 260 (not significantly different compared with control clone PB 260)

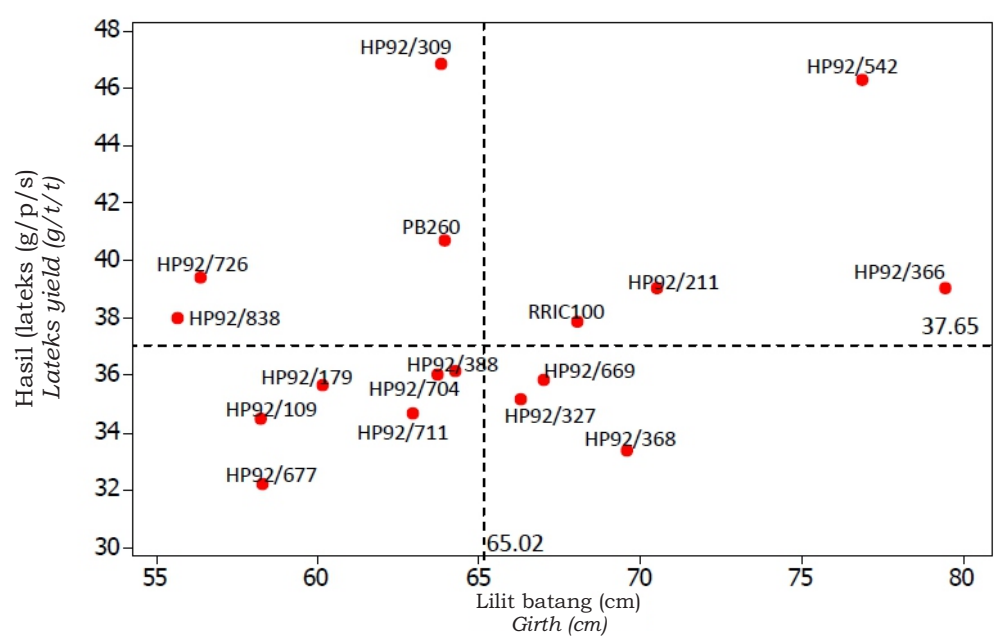

Gambar 1. Hubungan antara lilit batang dan hasil lateks 15 genotipe karet PP/07/04

Figure 1. Relationship between girth and latex yield of 15 rubber genotypes PP/O7/04

hubungan antara pertumbuhan lilit batang tanaman dan hasil lateks beberapa genotipe karet PP/07/04.

Berdasarkan pertumbuhan tanaman pada umur sebelas tahun seperti yang disajikan pada Tabel 1 dan Tabel 4 memperlihatkan bahwa genotipe HP 92/542, HP 92/211, HP 92/366 dan RRIC 100 tergolongan tanaman jagur, sedangkan genotipe HP 92/309, HP 92/726, HP 92/838 dan PB 260 tergolong tanaman dengan pertumbuhan sedang, namun genotipegenotipe tersebut memiliki rata-rata hasil lateks selama enam tahun tergolong tinggi. Genotipe HP 92/309 dan HP 92/542 memiliki hasil lateks nyata lebih tinggi dibandingkan dengan klon pembanding RRIC 100 dan PB 260. Berdasarkan karakter 
pertumbuhan tanaman dan hasil lateks dapat disimpulkan bahwa genotipe HP 92/309 memiliki potensi hasil lateks tinggi, sedangkan genotipe HP 92/542 memiliki potensi hasil lateks tinggi dan pertumbuhan jagur.

\section{Pendugaan Nilai Ragam Genetik dan Heritabilitas}

Nilai pendugaan komponen ragam, heritabilitas arti luas, dan koefisien keragaman genetik (KKG) beberapa karakter kuantitatif genotipe PP/07/04 disajikan pada Tabel 5. Hasil analisis data pada Tabel 5 menunjukkan bahwa nilai ragam genotipe pada setiap karakter yang diamati menunjukkan lebih rendah dibandingkan dengan nilai ragam fenotipenya. Hal tersebut menunjukkan adanya pengaruh lingkungan terhadap karakter yang diamati. Pengaruh lingkungan menyebabkan nilai ragam fenotipe menjadi lebih besar.

Tabel 5 menunjukkan bahwa karakter lilit batang, tebal kulit, jumlah cincin pembuluh lateks, diameter sel pembuluh lateks, panjang alur sadap, kecepatan aliran lateks, indeks penyumbatan, kadar fosfat anorganik, kadar sukrosa, kadar thiol, kadar karet kering, dan hasil lateks memiliki nilai heritabilitas arti luas $\left(\mathrm{h}^{2} \mathrm{bs}\right)$ tergolong tinggi. Nilai heritabilitas yang tinggi pada semua karakter yang diamati menunjukkan bahwa karakter-karakter tersebut lebih dipengaruhi oleh faktor genetik dibandingkan oleh lingkungan. Menurut Syukur dan Sobir (2015), karakter yang memiliki nilai heritabilitas sedang sampai tinggi maka karakter tersebut lebih dikendalikan oleh faktor genetik dibandingkan dengan lingkungan. Apabila suatu karakter memiliki nilai heritabilitas arti luas tinggi, maka karakter tersebut potensial untuk diwariskan kepada keturunan. Hasil penelitian menunjukkan bahwa heritabilitas karakter yang diamati memiliki kisaran nilai antara 0,52 - 0,95. Sudarmadji Mardjono dan Sudarmono (2007) menyatakan bahwa heritabilitas adalah proporsi ragam fenotipik total yang disebabkan oleh semua tipe efek gen. Nilai heritabilitas digolongkan menjadi tiga kriteria yaitu nilai heritabilitas rendah $\left(\mathrm{h}^{2}<\right.$ $0,2)$, heritabilitas sedang $\left(0,2<\mathrm{h}^{2}<0,5\right)$, dan heritabilitas tinggi $\left(0,5<\mathrm{h}^{2} \leq 1,0\right)$.

Tabel 5 menunjukkan nilai KKG pada masing-masing karakter kuantitatif.

Tabel 5. Nilai pendugaan komponen ragam, heritabilitas, dan koefisien keragaman genetik beberapa karakter kuantitatif genotipe karet harapan PP/07/04.

Table 5. Estimating value of variance component, heritability, and coefficient of genetic variability of some quantitative characters of rubber promising genotypes PP/07/04.

\begin{tabular}{lrrrrr}
\hline \multicolumn{1}{c}{ Karakter } & \multicolumn{1}{c}{$\sigma^{2} \mathrm{p}$} & \multicolumn{1}{c}{$\sigma^{2} \mathrm{~g}$} & \multicolumn{1}{c}{$\sigma^{2} \mathrm{e}$} & $\mathrm{h}^{2} \mathrm{bs}$ & \multicolumn{1}{c}{ KKG } \\
\hline Lilit batang $(\mathrm{cm})$ & 43,80 & 39,07 & 4,73 & 0,89 & 9,61 \\
Tebal kulit (mm) & 0,38 & 0,31 & 0,07 & 0,81 & 6,00 \\
Jumlah cincin pembuluh lateks & 7,80 & 4,07 & 3,73 & 0,52 & 14,40 \\
Diameter sel pembuluh lateks $(\mu \mathrm{m})$ & 5,89 & 5,61 & 0,28 & 0,95 & 10,77 \\
Panjang alur sadap (mm) & 19,40 & 16,00 & 3,40 & 0,82 & 11,03 \\
Kecepatan aliran lateks $(\mathrm{ml} /$ menit) & 53,70 & 44,90 & 8,80 & 0,84 & 39,96 \\
Indeks penyumbatan (\%) & 32,83 & 29,47 & 3,37 & 0,90 & 30,39 \\
Kadar fosfat anorganik (mM) & 10,28 & 8,40 & 1,84 & 0,82 & 20,77 \\
Kadar sukrosa (mM) & 14,69 & 13,83 & 0,86 & 0,94 & 61,78 \\
Kadar thiol (mM) & 0,026 & 0,02 & 0,003 & 0,77 & 28,85 \\
Kadar karet kering (\%) & 11,11 & 8,32 & 2,79 & 0,75 & 9,00 \\
Hasil lateks $(\mathrm{g} / \mathrm{p} / \mathrm{s})$ & 91,53 & 85,10 & 6,43 & 0,93 & 25,48 \\
\hline Keter
\end{tabular}

Keterangan (Remaks) $\sigma^{2} \mathrm{p}=$ ragam fenotipe(phenotypic variance); $\sigma^{2} \mathrm{~g}=$ ragam genotipe(genotypic variance); $\sigma^{2} \mathrm{e}=$ ragam lingkungan(environment variance), $\mathrm{h}^{2} \mathrm{bs}=$ heritabilitas arti luas(heritability),

$\mathrm{KKG}=$ koefisien keragaman genetik(coefficient of genetic variability) 
KKG paling tinggi terdapat pada karakter kadar sukrosa $(61,78 \%)$, sedangkan yang terendah terdapat pada karakter tebal kulit $(6,00 \%)$. Karakter lainnya memiliki KKG berkisar antara 9,00-39,96\%. Alnopri (2014) menyatakan bahwa keragaman genetik yang tinggi menunjukkan adanya pengaruh genetik yang lebih dominan daripada pengaruh lingkungan, sebaliknya keragaman genetik yang rendah menunjukkan adanya pengaruh lingkungan yang kuat. Berdasarkan analisis komponen ragam, heritabilitas, dan koefisien keragaman genetik dapat diketahui bahwa perwarisan karakter kuantitatif yang diamati lebih cenderung dipengaruhi oleh faktor genetik dibandingkan faktor lingkungan.

\section{KESIMPULAN}

Dari hasil penelitian dapat disimpulkan bahwa genotipe berpengaruh nyata pada parameter lilit batang, tebal kulit, jumlah cincin pembuluh lateks, diameter sel pembuluh lateks, panjang alur sadap, kecepatan aliran lateks, indeks penyumbatan, kadar fosfat anorganik, kadar sukrosa, kadar thiol, kadar karet kering, dan daya hasil lateks. Berdasarkan karakter pertumbuhan dan daya hasil lateks menunjukkan bahwa genotipe HP 92/309 memiliki potensi hasil lateks tinggi, sedangkan genotipe HP 92/542 memiliki potensi lateks tinggi dan pertumbuhan jagur. Semua karakter yang diamati memiliki nilai heritabilitas tinggi dengan nilai $h^{2}$ bs antara 0,52 - 0,95. Hal ini menunjukkan bahwa karakter-karakter tersebut dipengaruhi oleh faktor genetik. Untuk mengetahui daya adaptabilitas dan stabilitas pertumbuhan dan hasil lateks, maka perlu dilakukan pengujian skala lebih luas pada genotipe HP 92/309 dan HP 92/542 pada beberapa agroekosistem.

\section{DAFTAR PUSTAKA}

Aidi-Daslin., Woelan, S., Lasminingsih, M., \& Hadi, H. (2009). Kemajuan pemuliaan dan seleksi tanaman karet di Indonesia. Prosiding Lokakarya Nasional Pemuliaan Tanaman Karet 2005 (pp. 50-59). Medan, Indonesia: Pusat Penelitian Karet.
Aidi-Daslin. (2011). Evaluasi pengujian lanjutan klon karet IRR seri 200 pada masa tanaman belum menghasilkan. Jurnal Penelitian Karet, 29(2), 93-101.

Aidi-Daslin., Sayurandi., \& Pasaribu, S. A. (2012). Potensi keunggulan klon karet harapan IRR seri 200 dari hasil seleksi pohon induk. Jurnal Penelitian Karet, 30(1), 1-10.

Aidi-Daslin. (2012). Evaluasi pengujian lanjutan klon karet IRR seri 120-140. Jurnal Penelitian Karet, 30(2), 65-74.

Alnopri. (2014). Variabilitas genetik dan heritabilitas karakter-karakter pertumbuhan bibit kopi robustaarabika. J Imu Pertanian Indonesia, 6, 91-96.

Annamalainathan, K., Krihsnakumar, R., \& Jacob, J. (2001). Tapping-induced changes in respiratory metabolism. ATP production and reactive oxygen species scavenging in Hevea. J. Rubber. Res, 4(4), 245-254.

Atminingsih. (2015). Respon fisiologi lateks dan histologi pembuluh lateks berapa klon terhadap konsentrasi stimulan yang berbeda pada tanaman karet (Hevea brasiliensis Muell Arg.) (Tesis), Universitas Sumatera Utara, Indonesia.

Departemen Pertanian. (2014). Luas areal, produksi dan produktivitas perkebunan di Indonesia tahun 2013. Diakses dari www.pertanian.go.id tanggal 5 Mei 2015.

Direktorat Jenderal Perkebunan. (2010). Statistik Perkebunan Indonesia 2009 2010. Jakarta, Indonesia: Dirjenbun.

Gomez, J., Narayanan, R., \& Chen, K. T. (1982). Some structural factors affecting the productivity of Hevea brasiliensis Muell Arg. J. Rubb. Res. Institute Malaya, 23(3), 193-203.

Herlinawati, E., \& Kuswanhadi. (2013). Aktifitas metabolisme beberapa klon karet pada berbagai frekuensi sadap dan stimulasi. Jurnal Penelitian Karet, 31(2), 102-109. 
Milford,G. F. J., Paardekooper, E. C., \& Ho, C. V. (1969). Latex vessel plugging : Its importance to yield and clonal behavior. J. Rubb. Res. of Malaya, 21, $274-282$.

Mirabello, M. J., Yavitt, J. B., Garcia, M., Harms, K. E., Turner, B. L., \& Wright, S. J. (2013). Soil phosphorus responses to chronic nutrient fertilisation and seasonal drougth in a humid lowland forest Panama. $J$ Soil Res., 51, $215-221$. D o i : 10.1071/SR12188.

Novalina, Jusuf, M., Wattimena, G. A., Suharsono., Sumarmadji., \& AidiDaslin. (2008). Keragaan dan hubungan berbagai komponen hasil tanaman karet (Hevea brasiliensis Muell Arg.) pada dua populasi hasil persilangan PB 260 dan PN. Bul. Agron, 36(2), 152-159.

Novalina. (2009). Deteksi marka genetik yang terpaut dengan komponen produksi lateks pada tanaman karet (Hevea brasiliensis Muell Arg.) melalui pemetaan QTL (Disertasi), Institut Pertanian Bogor, Indonesia

Obouayeba, S., Soumahin, E. F., Okoma, K. M., Nguessan, A. E. B., Coulibaly, L. F., Koffi, K. E., \& Lacote, R. (2012). Temporal and structural relations within bark and trunk in Hevea brasiliensis. Journal of Biosciences, 2(2), 56-71.

Purwaningrum, Y., Napitupulu, J. A., Siregar, T. H. S., \& Hanum, C. (2015). Histology and physiology of BPM1 clones with different exploitation systems. J Bas \& App Res., 21(1), 138148.

Rachmawan, A., \& Sumarmadji. (2007). Kajian karakter fisiologi dan sifat karet klon PB 260 menjelang buka sadap. Jurnal Penelitian Karet, 25(2), 59-70.

Siagian, N., \& Siregar, T. H. S. (2013). Evaluasi produktivitas tanaman karet dengan sistem ganda pada skala komersial. Warta Perkaretan, 32(1), 16-24.

Sudarmadji., Mardjono, R., \& Sudarmono, H. (2007). Variasi genetik, heritabilitas dan korelasi genotipik sifat-sifat penting tanaman wijen (Sesamum indicum L.). J Littri., 13(3), 88-92.

Sumarmadji., \& Tistama, R. (2004). Deskripsi klon karet berdasarkan karakter fisiologi lateks untuk menetapkan sistem eksploitasi yang sesuai. Jurnal Penelitian Karet, 22(1), 27-40.

Syukur, M., Sujiprihati, S., \& Yunianti, R. (2012). Teknik Pemuliaan Tanaman. Jakarta, Indonesia: Penebar Swadaya.

Syukur, M., \& Sobir. (2015). Genetika Tanaman. Bogor, Indonesia: IPB Press.

Woelan, S., Sayurandi., \& Pasaribu, S. A. (2012). Keragaan klon-klon IRR seri 300 dan 400 di pengujian plot promosi. Warta Perkaretan, 31(1), 1-10.

Woelan, S. (2013). Peta pautan genetik dan analisis QTL tanaman karet (Hevea brasiliensis Muell Arg.) pada populasi hasil persilangan RRIM 600 dan PN 1546 sebagai dasar strategi peningkatan produksi lateks (Disertasi), Universitas Sumatera Utara, Indonesia.

Woelan, S., Sayurandi., \& Pasaribu, S. A. (2013). Karakter fisiologi, anatomi, pertumbuhan dan hasil lateks klon IRR seri 300. Jurnal Penelitian Karet, 31(1), 1-12.

Woelan, S., Sayurandi., \& Irwansyah, E. (2014). Keragaman genetik tanaman karet (Hevea brasiliensis Muell Arg) dari hasil persilangan interspesifik. Jurnal Penelitian Karet, 32(2), 109. 121.

Zambrosi, F. C. B., Junior, D. M., Boaretto, R. M., Quaggio, J. A., Muraoka, T., \& Syvertsen, J. P. (2012). Contribution of phosphorus $\left({ }^{32} \mathrm{P}\right)$ absorption and remobilization for citrus growth. $J$ Plant Soil., 255, 353-362. Doi: 10.1007/s11104-011-1107-1. 